University of Nebraska - Lincoln

DigitalCommons@University of Nebraska - Lincoln

USGS Staff -- Published Research

US Geological Survey

2012

\title{
Global air temperature variability independent of sea-surface temperature influences
}

Andrew C. Comrie

University of Arizona, comrie@arizona.edu

GregoryJ. McCabe

US Geological Survey

Follow this and additional works at: http://digitalcommons.unl.edu/usgsstaffpub

Part of the Geology Commons, Oceanography and Atmospheric Sciences and Meteorology Commons, Other Earth Sciences Commons, and the Other Environmental Sciences Commons

Comrie, Andrew C. and McCabe, Gregory J., "Global air temperature variability independent of sea-surface temperature influences" (2012). USGS Staff-- Published Research. 907.

http:// digitalcommons.unl.edu/usgsstaffpub/907

This Article is brought to you for free and open access by the US Geological Survey at DigitalCommons@University of Nebraska - Lincoln. It has been accepted for inclusion in USGS Staff -- Published Research by an authorized administrator of DigitalCommons@University of Nebraska - Lincoln. 
Global air temperature variability independent of sea-surface temperature influences
Progress in Physical Geography 37(I) 29-35

(C) The Author(s) 2012 Reprints and permission: sagepub.co.uk/journalsPermissions.nav DOI: I0.1|77/0309|333|2460074 Ppg.sagepub.com

@SAGE

\author{
Andrew C. Comrie \\ University of Arizona, USA \\ Gregory J. McCabe \\ US Geological Survey, USA
}

\begin{abstract}
Mean global surface air temperature (SAT) and sea surface temperature (SST) display substantial variability on timescales ranging from annual to multi-decadal. We review the key recent literature on connections between global SAT and SST variability. Although individual ocean influences on SAT have been recognized, the combined contributions of worldwide SST variability on the global SAT signal have not been clearly identified in observed data. We analyze these relations using principal components of detrended SST, and find that removing the underlying combined annual, decadal, and multi-decadal SST variability from the SAT time series reveals a nearly monotonic global warming trend in SAT since about 1900.
\end{abstract}

\title{
Keywords
}

climate change, climate variability, global change, global temperature, sea-surface temperature

\section{Review}

\section{Introduction}

Changes in annual mean global surface air temperature (SAT) are at the heart of current climate change science and policy. Graphical images of the SAT time series, like the Mauna Loa carbon dioxide curve, have taken on almost iconic status as a primary illustration of climate change. In addition to a long-term positive trend in SAT, another major feature of the SAT time series is multi-decadal variability: a warming in the early 20th century, a cooling in roughly mid-century, and an increase again since the mid-1970s. The multi-decadal SAT variability may be controlled by multi-decadal variability of the world's oceans (Baines and Folland, 2007; Knight et al., 2005; Kravtsov and Spannagle, 2008; Parker et al., 2007; Swanson et al., 2009; Zhang et al., 2007).

A number of studies during recent years have indicated that sea-surface temperatures (SSTs) have a significant effect on the variability of global temperatures (Compo and Sardeshmukh, 2010; Keenlyside et al., 2008; Kelly and Jones,

\section{Corresponding author:}

Andrew C. Comrie, School of Geography and Development, University of Arizona, Tucson, AZ 8572I, USA.

Email: comrie@arizona.edu 
1996; Kerr, 2008; Kravtsov and Spannagle, 2008; Robock and Mao, 1995; Sutton and Hodson, 2007; Thompson et al., 2009). In a study of global temperature change during the 19th and 20th centuries Andronova and Schlesinger (2000) suggest that anthropogenic effects are the dominant cause of global warming, but that there are additional factors that must be considered. They suggest that a possibly important driver of global temperature variability is North Atlantic Ocean SSTs; additionally, Keenlyside et al. (2008) suggest that natural variations of the North Atlantic and Pacific Oceans can temporally offset the effects of anthropogenic warming. In contrast, Hoerling et al. (2008) argue that natural internal variations of the climate system have had a small effect on global land temperatures.

In addition to the effects of SSTs on global temperature, research has indicated a number of interactions of SSTs in different ocean basins on each other. For example, some research suggests that anomalous Atlantic Ocean SSTs modulate both the mean and variability of Pacific Ocean SSTs (Dommenget, 2009; Dong and Sutton, 2007). Dong and Sutton (2007) showed that when the North Atlantic Ocean is anomalously cool, El Niño Southern Oscillation (ENSO) variability is enhanced. The Dong and Sutton (2007) study suggests the existence of an atmospheric bridge that transfers the influence of the Atlantic Ocean to the tropical Pacific and indicates that fluctuations of North Atlantic Ocean SSTs can influence mean global climate as well as interannual variability of global climate. In contrast, $\mathrm{Wu}$ et al. (2005) suggest that the North Pacific Ocean may be an important regulator of global decadal climate variability.

While the Northern Hemisphere mean surface temperature has clearly warmed over the 20th century, this warming has not been monotonic. The departures from steady warming on multidecadal timescales might be associated in part with radiative forcing, especially solar irradiance, volcanoes, and anthropogenic aerosols (Booth et al., 2012; Hoerling et al., 2008). It is also possible that internal oceanic variability explains a part of this variation. Zhang et al. (2007) suggest that variability in the Atlantic is a viable explanation for a portion of the multidecadal variability in the Northern Hemisphere mean temperature record. Similarly, Kravtsov and Spannagle (2008) found that, after subtracting the global warming signal estimated by climate models from observed global temperatures, the remaining signal resembled variability of the North Atlantic Ocean as represented by the Atlantic Multidecadal Oscillation (AMO). Kravtsov and Spannagle (2008) speculate that secular variability in the observed surface temperature is a combination of a global warming trend and a multidecadal oscillation similar to the AMO signal (Delworth and Mann, 2000; Knight et al., 2005). Similarly, Zhang et al. (2007) have argued that the direct contribution of multidecadal Atlantic SST variability to the global temperature signal is substantial.

\section{SAT variability independent of SST}

Based on review of the science to date, a key unanswered question arises as to the nature of SAT variability independent of the effects of global SST variability, excluding long-term trends in SST. Previous studies of the relations between SSTs and SAT have used combinations of measured data and climate-model simulated data (Kravtsov and Spannagle, 2008; Parker et al., 2007; Swanson et al., 2009; Zhang et al., 2007), and have often used filtering to remove high-frequency variability from the SSTs and SAT data (Kravtsov and Spannagle, 2008; Swanson et al., 2009; Zhang et al., 2007). No study to date has explicitly identified the trend in SAT with SST influence removed, based simply on unfiltered instrumental data for both series. We therefore carried out this analysis to confirm results from previous studies, particularly model-based studies, and to quantify 
the combined effect of global SSTs on SAT. Additionally, this enabled us to identify the trend in SAT when annual, decadal, and multidecadal SST variability is removed.

\section{Data and methods}

Monthly mean global land surface air temperature time series for the period 1856 through 2011 was obtained from the Climatic Research Unit at the University of East Anglia (i.e. data set CRUTEM3gl obtained from http:// www.cru.uea.ac.uk/cru/data/temperature). The monthly values of this time series were averaged to produce a time series of annual mean global temperature. We used mean global land surface temperature, rather than the combined land and marine temperature time series, to examine the independent effects of SST variability on land surface temperature.

Monthly SSTs for 1856 through 2011 were obtained from the Kaplan extended SST data set (Kaplan et al., 1998) maintained by the US National Oceanic and Atmospheric Administration (www.cdc.noaa.gov/data/ gridded/data.kaplan_sst.html). The Kaplan SST data are on a 5 degree by 5 degree grid cell resolution. For the globe, there are 1207 grid cells with complete data for the 1856 through 2011 period. The monthly SST data were averaged to produce time series of annual mean SST for each of the 1207 grid cells with complete data.

The time series of annual mean SSTs for each grid cell also were detrended (by subtracting the simple linear trend for each grid cell) to remove any long-term warming or cooling trend that might be related to global climate change, thereby leaving SST variability on annual, decadal, and multi-decadal timescales. The trends in annual SSTs for the 1207 grid cells ranged from $-0.70^{\circ} \mathrm{C} / 100$ years to $1.09^{\circ} \mathrm{C} / 100$ years (with a median of $-0.311^{\circ} \mathrm{C} / 100$ years, and a 25th percentile of $-0.16^{\circ} \mathrm{C} / 100$ years and a 75 th percentile of $0.44^{\circ} \mathrm{C} / 100$ years).
The detrended SST data were then subjected to a principal components analysis (PCA) with varimax rotation to identify the primary modes of global SST variability. The resulting leading components of SST variability were used subsequently as independent variables in a multiple regression with SAT (as the dependent variable) and the SAT residuals were plotted and compared to the original SAT time series.

\section{Results}

The PCA of the SST data produced two principal components (PCs) that explained approximately $34 \%$ of the variance in global SST variability (Figure 1). PC1 explains $20 \%$ of the SST variability and PC2 explains $14 \%$ of the SST variability. Subsequent PCs explained $6 \%$ or less of the variability in the SST data.

The loading pattern for PC1 primarily reflects SST variability in the tropical and extratropical eastern Pacific Ocean, the Indian Ocean, and the western tropical Atlantic Ocean (Figure 1a). Given the large positive loadings in the eastern tropical Pacific Ocean and the pronounced interannual variability (Figure 1a), this mode of SST variability appears to be strongly associated with ENSO. ENSO is a primary mode of global climate variability (Kiladis and Diaz, 1989) and is driven by variability of SSTs in the eastern tropical Pacific Ocean. A widely used index of ENSO is the NINO3.4 SST index which is computed as the average of the SSTs for the region from $5^{\circ} \mathrm{N}$ latitude to $5^{\circ} \mathrm{S}$ latitude and from $170^{\circ} \mathrm{W}$ longitude to $120^{\circ} \mathrm{W}$ longitude (an annual time series of NINO3.4 values for 1856 through 2011 was computed using the Kaplan SST data set). The correlation between PC1 score time series and NINO3.4 seasurface temperatures is $0.89(\mathrm{p}<0.05)$.

The loading pattern of PC2 indicates SST variability in the tropical and extratropical western and central Pacific Ocean and the eastern North Atlantic Ocean (Figure 1b). This mode has relatively greater multidecadal variability 

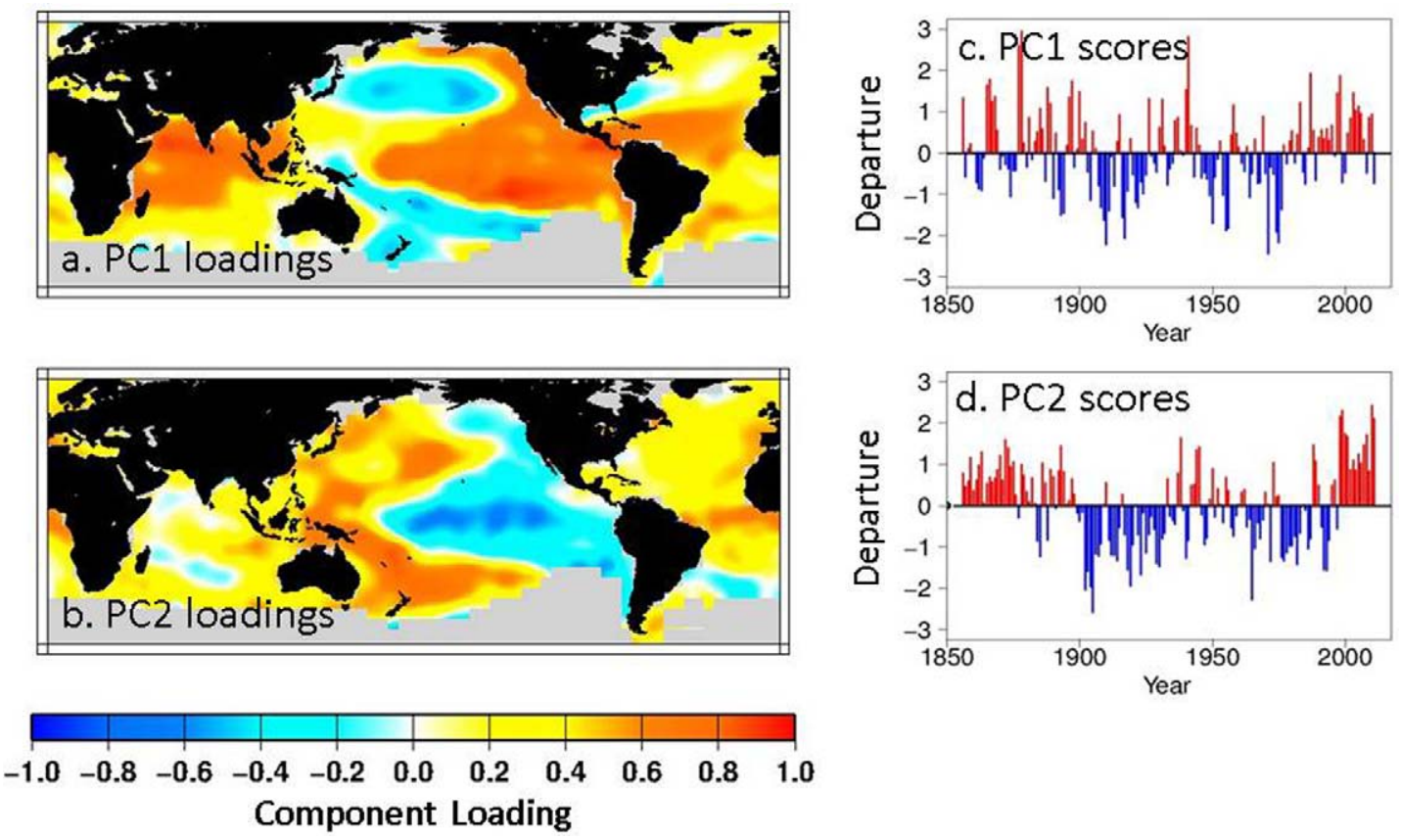

Figure I. Principal component loadings and scores for PCI and PC2 of detrended annual sea-surface temperatures, 1856-20II. Excluded SST grid cells, located mostly near the poles, are shaded gray.

(a) Component loadings for PCI. (b) Component loadings for PC2. (c) Component scores for PCI.

(d) Component scores for PC2. (See colour version of this figure online).

(Figure 1d) than PC1. Additionally, the positive loadings of PC2 in the North Atlantic Ocean (Figure 1b) and the temporal variability of PC2 score time series (Figure 1d) suggest spatial and temporal patterns similar to the Atlantic Multidecadal Oscillation (AMO). The AMO is an index of SSTs in the North Atlantic Ocean between the equator and $70^{\circ} \mathrm{N}$ (Enfield et al., 2001). A single mode of SST variability of the entire North Atlantic basin, exhibiting a longterm, quasi-cyclic variation at timescales of 50-70 years was first noted in the North Atlantic by Schlesinger and Ramankutty (1994). More recent research also reveals that multidecadal variability in North Atlantic climate is dominated by a single mode of SST variability (Knight et al., 2006; Sutton and Hodson, 2003). A time series of annual AMO values for 1856 through 2011 was computed using the Kaplan data set. The correlation between the
PC2 scores and mean annual values of AMO is $0.68(\mathrm{p}<0.05)$.

The multiple regression of the two PCs (independent variables) against SAT (dependent variable) indicated that $22 \%$ of the SAT variability is explained by these two PCs (the regression was statistically significant at the $99 \%$ confidence level). The regression coefficient for PC1 is $0.08(p<0.01)$ and the coefficient for $\mathrm{PC} 2$ is $0.14(\mathrm{p}<0.01)$. It is interesting that the regression coefficient for PC2 (the AMO signal) is greater than the regression coefficient for $\mathrm{PC} 1$ (the ENSO signal). In comparison, a linear trend through the original SAT time series explains $62 \%$ of the SAT variability. Thus, a linear trend and the two SST PCs account for $84 \%$ of the variability in SAT.

The residuals of SAT (from the regression on SST PC1 and SST PC2) indicate a more monotonic trend in SAT than does the original 

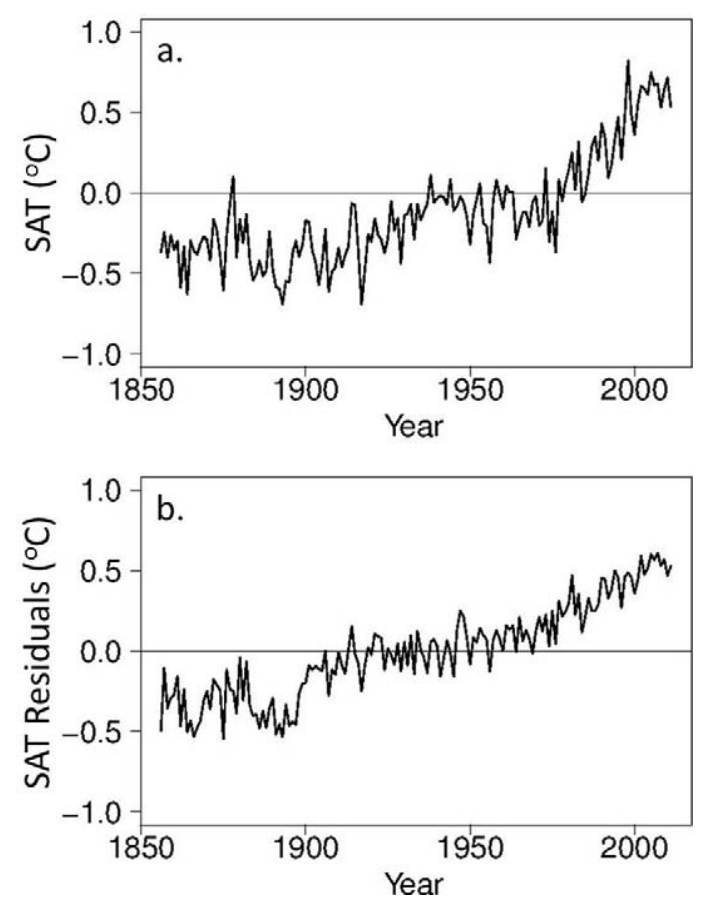

Figure 2. (a) Annual mean global surface air temperature (SAT) departures from 1961-1990 mean.

(b) SAT residuals after removing the effects of detrended sea-surface temperatures, I856-20II.

time series (Figure 2). The linear trend in the SAT residuals for the period 1900 through 2011 , however, is $0.58^{\circ} \mathrm{C} / 100$ years, which is the same as the linear trend in the original SAT time series. In contrast, the linear trend in the SAT residuals since about 1950, when the monotonic increase in SAT is most apparent, is $0.96^{\circ} \mathrm{C} / 100$ years. Additionally, there appears to be a discontinuity in the time series of SAT residuals after about 1900 which may be related to the number of observations used to compute the global mean annual temperature.

Removing both interannual and multidecadal SST variability from the observed global mean SAT record results in a climate signal that is monotonic (Swanson et al., 2009; Thompson et al., 2009). Swanson et al. (2009) used a suite of climate model simulations to examine resultant global mean temperature variability after removing internal natural climate variability driven by SSTs. They showed that removing the natural variability of SSTs from global mean temperature resulted in a monotonic warming trend during the 20th century. Thompson et al. (2009) used a series of methods to isolate the effects of three known sources of natural variability (ENSO, variations in the advection of marine air masses over the high-latitude continents during winter, and aerosols injected into the stratosphere by volcanic eruptions) on global temperature. After removing the effects of these sources of natural variability from the temperature time series the residual time series showed a nearly monotonic global warming pattern since about 1950 . Our results are distinct from and complementary to these two studies because (1) they are based on observed rather than modeled data and (2) they include consideration of all sources of ocean-related variability together rather than separate signals.

\section{Concluding discussion}

Trends and variability in global SAT are closely linked with trends and variability in global SST. Empirical and modeling studies have detailed the connections between these quantities, including the individual roles of higher and lower frequency modes of variability such as ENSO and multidecadal quasi-oscillations. No studies to date have identified the combined effects of worldwide observed SST variability on the global SAT signal. An analysis of this question confirms the findings of previous studies that SST variability has an influence on SAT (Kravtsov and Spannagle, 2008; Parker et al., 2007; Swanson et al., 2009; Zhang et al., 2007). The results presented here are based solely on measurements and indicate that SST variability accounts for about $24 \%$ of the variability in SAT. Removing the effect of detrended SST variability provides a modified time series of underlying SAT behavior. Given the 
Progress in Physical Geography 37(I)

symbolic importance of the global SAT curve, there is value in visualizing the resulting monotonic warming signal for both scientific and public audiences. These results suggest that (1) natural climate variability of global SSTs has masked the global warming trend during some periods, (2) global SST variability has likely enhanced and reduced the SAT warming signal during different periods, (3) a consistent underlying SAT warming, distinct from annual and multi-decadal SST variability, has been taking place since about 1900, and (4) climate models need to reliably simulate SST variability and SST effects on global temperature to accurately simulate future climate.

\section{Funding}

This research received no specific grant from any funding agency in the public, commercial, or notfor-profit sectors.

\section{References}

Andronova NG and Schlesinger ME (2000) Causes of global temperature changes during the 19th and 20th centuries. Geophysical Research Letters 27: 2137-2140.

Baines PG and Folland CK (2007) Evidence for a rapid global climate shift across the late 1960s. Journal of Climate 20: 2721-2744.

Booth BB, Dunstone NJ, Halloran PR, et al. (2012) Aerosols implicated as a prime driver of twentiethcentury North Atlantic climate variability. Nature 484: 228-232.

Compo GP and Sardeshmukh PD (2010) Removing ENSO-related variations from the climate record. Journal of Climate 23: 1957-1978.

Delworth TL and Mann ME (2000) Observed and simulated multidecadal variability in the Northern hemisphere. Climate Dynamics 16: 661-676.

Dommenget D (2009) The ocean's role in continental climate variability and change. Journal of Climate 22: 4939-4952.

Dong BW and Sutton RT (2007) Enhancement of El NinoSouthern Oscillation (ENSO) variability by a weakened Atlantic thermohaline circulation in a coupled GCM. Journal of Climate 20: 4920-4939.
Enfield DB, Mestas-Nuñez AM, and Trimble PJ (2001) The Atlantic multidecadal oscillation and its relation to rainfall and river flows in the continental USA. Geophysical Research Letters 28: 2077-2080.

Hoerling M, Kumar A, Eischeid J, et al. (2008) What is causing the variability in global mean land temperature? Geophysical Research Letters 35: L23712.

Kaplan A, Cane M, Kushnir Y, et al. (1998) Analyses of global sea surface temperature 1856-1991. Journal of Geophysical Research 103: 18567-18589.

Keenlyside NS, Latif M, Jungclaus J, et al. (2008) Advancing decadal-scale climate prediction in the North Atlantic sector. Nature 453: 84-88.

Kelly PM and Jones PD (1996) Removal of the El NiñoSouthern Oscillation signal from the gridded surface air temperature data set. Journal of Geophysical Research 101: D14.

Kerr RA (2008) Humans and nature duel over the next decade's climate. Nature 317: 746-747.

Kiladis GN and Diaz HF (1989) Global climatic anomalies associated with extremes of the Southern Oscillation. Journal of Climate 2: 1029-1090.

Knight JR, Allan RJ, Folland CK, et al. (2005) A signature of persistent natural thermohaline circulation cycles in observed climate. Geophysical Research Letters 32: L20708.

Kravtsov S and Spannagle C (2008) Multidecadal climate variability in observed and modeled surface temperature. Journal of Climate 21: 1104-1121.

Parker D, Folland C, Scaife A, et al. (2007) Decadal to multidecadal variability and the climate change background. Journal of Geophysical Research 112: D18115.

Robock A and Mao J (1995) The volcanic signal in surface temperature observations. Journal of Climate 8: 1086-1103.

Schlesinger ME and Ramankutty N (1994) An oscillation in the global climate system of period 65-70 years. Science 367: 723-726.

Sutton RT and Hodson DLR (2003) Influence of the ocean on North Atlantic climate variability 1871-1999. Journal of Climate 16: 3296-3313.

Sutton RT and Hodson DLR (2007) Climate response to basin-scale warming and cooling of the North Atlantic Ocean. Journal of Climate 20: 891-907.

Swanson KL, Sugihara G, and Tsonis AA (2009) Longterm natural variability and 20th century climate 
change. Proceedings of the National Academy of Sciences 106: 16120-16123.

Thompson DWJ, Wallace JM, Jones PD, et al. (2009) Identifying signatures of natural climate variability in time series of global-mean surface temperature: methodology and insights. Journal of Climate 22: 6120-6141.
Wu L, Liu Z, Liu Y, et al. (2005) Potential global climatic impacts of the North Pacific Ocean. Geophysical Research Letters 32: L24710.

Zhang R, Delworth DL, and Held I (2007) Can the Atlantic Ocean drive the observed multidecadal variability in Northern Hemisphere mean temperature. Geophysical Research Letters 34: L02709. 